\section{Low-Al and high-Mg amphiboles in the Ciomadul dacitic pumice suggest ultrahydrous primary mafic magma}

\author{
BARBARA CSERÉP ${ }^{1}$, ZOLTÁN KOVÁCS ${ }^{2}$, RÉKA \\ LUKÁCS $^{3}$ AND SZABOLCS HARANGI ${ }^{3}$ \\ ${ }^{1}$ Eötvös Loránd University \\ ${ }^{3}$ MTA-ELTE Volcanology Research Group \\ Presenting Author: cserep.barbara@gmail.com
}

${ }^{2}$ MTA-ELTE

Ciomadul is the youngest volcano in eastern-central Europe where the last eruption occurred at $30 \mathrm{ka}$. It is now in a dormant stage but geophysical data indicate existence of melt-bearing subvolcanic magma body that is consistent with zircon geochronological data implying long residence time of the magma reservoir. Understanding the rejuvenation of this longstanding crystal-mush is crucial to evaluate the nature of longdormant volcanoes. Here, we explore this issue focusing on high$\mathrm{Mg}$ mafic minerals found in dacitic pumices from the oldest, 57$50 \mathrm{ka}$ explosive eruption products formed after a long, ca. $40 \mathrm{kyr}$ dormancy. The $57 \mathrm{ka}$ pumices contain amphibole crystal aggregates with orthopyroxene and clinopyroxene cores. Furthermore, high-Mg amphibole inclusions are also found in pyroxenes. Remarkably, these amphiboles have low $\mathrm{Al}_{2} \mathrm{O}_{3}$ content $(<9 \mathrm{wt} \%)$ and have similar compositions to some of the amphibole macrocryst cores found in 50 ka pumices. Such high$\mathrm{Mg}$ amphiboles are commonly interpreted as liquidus phases crystallized from ultrahydrous melt, although they have higher $\mathrm{Al}$ content. Remarkably, such low-Al and high-Mg amphiboles found in the Ciomadul pumices have not been produced by experiments.

Trace element content of these peculiar amphiboles is distinct having overall low concentrations. They have notable heavy REE depletion and a relative enrichment in $\mathrm{Ba}$ and $\mathrm{Sr}$. We compared these particular trace element signature along with the major element character with $>40$ thousand amphibole data retrieved from the GEOROC data-base. Among them, only a few show similar compositional pattern, the closest one is amphibole vein in metasomatized peridotite from Baikal. This finding is consistent with the view that the primary magmas of the Ciomadul dacites could have been formed by melting of a strongly metasomatized lithospheric mantle peridotite. Low degree melting of such lithology could result in an ultrahydrous primary melt from which amphibole can crystallize among the first phases. The high $\mathrm{Cr}$ content along with the $\mathrm{Cr}$-rich spinel inclusions in the amphiboles indicate a strongly depleted peridotite source. Ascent of such hydrous mafic magma to the upper crustal felsic crystal-mush could initiate rapid rejuvenation and volatile oversaturation ultimately leading to explosive eruptions after long quiescence.

This research belongs to NKFIH-K135179 project.
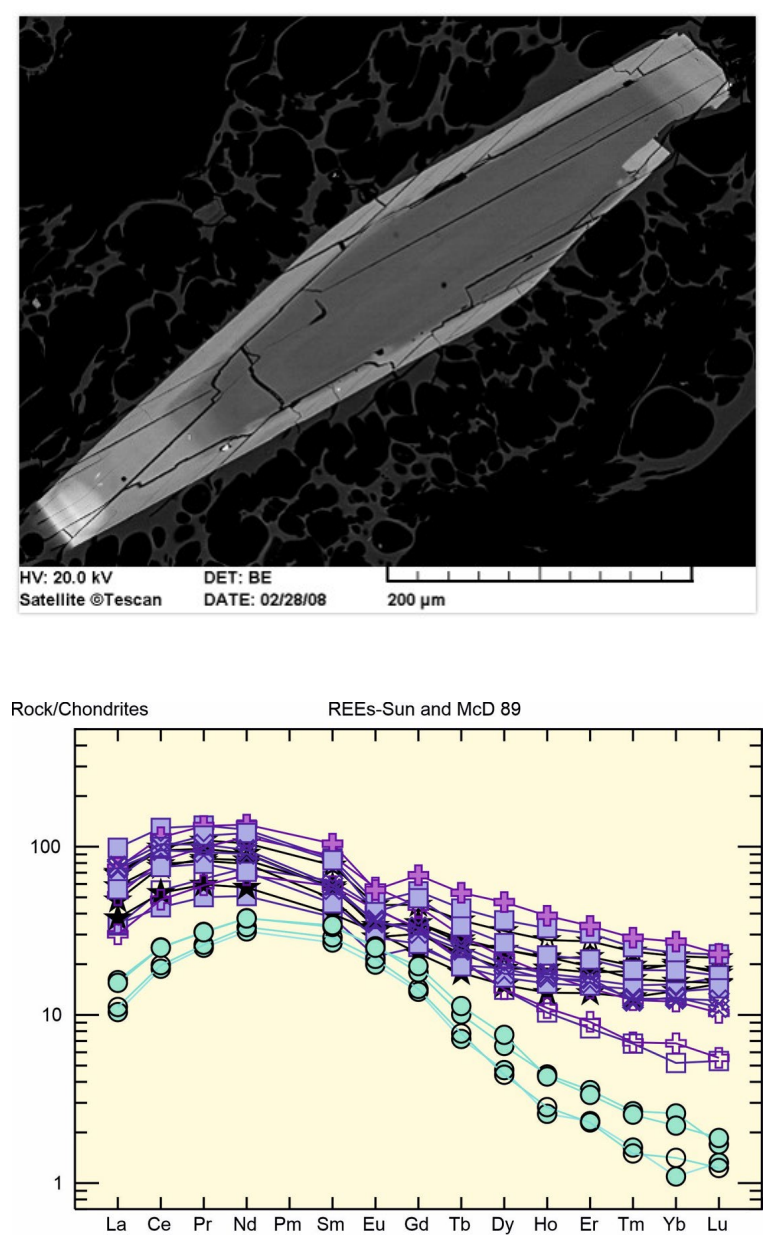